\title{
Analysis and Trends of Hostel Development in the Regional Tourist Market
}

\author{
N.V. Glebova*, V.A. Kozlova, N.I. Tsareva, Yu.V. Rogacheva \\ Oryol State University named after I. S. Turgenev, Oryol 302026, Russia \\ *Corresponding author. Email: nat.vic.gleb@mail.ru
}

\begin{abstract}
The article is devoted to the development of hostels in the regional tourist market. The authors of the article analyze and examine the trends in the development of hostels in the Oryol region. Based on the research results, further prospects for the development of the hostel market as a component of the development of the regional tourism market are predicted.
\end{abstract}

Keywords: tourism, hostel, regional market

\section{INTRODUCTION}

Nowadays tourism is a significant incentive for social and economic development of the society, a powerful mechanism for the economy recovery. The tourist and recreational potential of Russia is immense. It ranks fifth in the world in terms of unique natural sites and ninth in terms of historical and cultural heritage [1].

Currently, the term "regional tourism" is often used in the professional lexicon, which is usually associated with a clearly defined territorial unit - federation unit. The increased interest in the regional dimension of tourism is now quite logical.

The search for new methods to improve the industrial unit attracts attention of many tourist market participants who provide recreational services.

The Oryol region, along with the problems typical for the majority of the Russian regions, has a number of significant advantages in the tourism sector. They are as follows: favorable transport location, climatic conditions, natural resources, sites of the historical and cultural heritage, and dynamically expanding contacts with the representatives of Russian and foreign business. The tourism potential of the region offers the possibility to develop almost all types of tourism successfully, including such related sectors as excursion, museum, transport services, hotel industry, catering, etc.

The regional tourism market is a favorable environment for small businesses to operate, for this reason many entrepreneurs seek to enter this market with a small startup cost. Speaking about hotel facilities, recently small bare bones collective accommodation facilities, known as hostels, gain more popularity.

\subsection{Related Work}

Hostels are a relatively new type of temporary accommodation for the Russian economy. Despite the fact that different countries have their own hostel peculiarities, their common features are as follows: dorm rooms with minimalistic furnishing, shared room for having meals, shared facilities and a relatively low price. The Russian legislation defines the following key features of a hostel: the availability of multi-bed dorm rooms (no more than 12 beds), a sanitary zone, usually outside the room, as well as public circulations. [2].

For a long time, hostels as an independent niche of low-cost collective accommodation facilities remained almost unoccupied in Russia. Recently, against the background of the economic decline, hostels have become the most dynamically developing segment of the Russian hospitality industry. However, legislative changes adopted in 2019 put the future of the Russian hostel market at risk. The ban on locating hostels in apartment blocks after October 1, 2019 was regarded as an extremely negative factor that significantly penalizes the business environment by many experts.

In Russia, hostels are considered to be low-cost analogues of hotels that perform two main functions: low-cost accommodation and small business development. In world's practice, their functions were much broader, for example, regulation of migration processes [3], or partial rehabilitation of vulnerable groups - homeless population, people suffering from alcoholism, etc. [4,5].

In the modern society, hostels are a part of the tourist infrastructure that participate in supporting social mobility of the population $[6,7,8]$. In recent decades, for "millennials", living in hostels is an excellent opportunity for social interaction, which is not possible within the framework of a regular hotel service. The conducted research $[9,10,11]$ enables to conclude that hostels in the modern tourist market are in a transformation state, adapting to the needs and values of travelers and are considered to be an independent product, with its own special set of factors that determine its value, the quality of which is subject to increasingly high requirements. In this regard, the question to what extent Russian hostels, in particular, in the regional market, meet the requirements is of great interest. 


\subsection{Our Contribution}

The article presents the analysis results and examines the hostel development trends in the regional tourist market. It should be noted that conducting an analysis of the hostel market is quite challenging, since most reports of official statistics and research companies do not take into account mini-hotels and hostels. Primary information was collected in open access resources: on microsites, electronic versions of magazine publications, large tourist portals, etc. To solve the target problem, the information analysis on hostels in the regional market was conducted, hosted on websites for hotels and hostels reservations, in particular, the data from the website booking.com was used in the article.

\section{BACKGROUND}

As of this date, according to the site booking.com, the following accommodation options are available in Oryol: hotels, apartments, hostels, guest houses, cottage complexes, motels.

There are six operating hostels in the analyzed region, Table 1.

Table 1 Relative share of hostels among accommodation facilities in Oryol

\begin{tabular}{|c|l|c|c|}
\hline № & \multicolumn{1}{|c|}{ Accommodation options } & $\begin{array}{c}\text { Amount of } \\
\text { facilities }\end{array}$ & $\begin{array}{c}\text { Relative } \\
\text { share, \% }\end{array}$ \\
\hline 1 & Hotels & 20 & 17,7 \\
\hline 2 & Apartments & 80 & 70,8 \\
\hline 3 & Hostels & 6 & 5,3 \\
\hline 4 & Guest houses & 3 & 2,7 \\
\hline 5 & Cottage complexes & 3 & 2,7 \\
\hline 6 & Motels & 1 & 0,8 \\
\hline
\end{tabular}

The share of hostels from the total number of hotel facilities in the town is $5.3 \%$. In 2016 there were 3 hostels in Oryol; in 2017 there was an increase in demand for hostel services that contributed to an increase in their number: 2 more hostels with 34 places of accommodation were opened. In 2018 Oryol market for hotel services experienced stagnation in the hostel sector: two hostels were closed. At present booking.com issues at the request 6 hostels in Oryol: "DeVu", "Gurteva", "Chisto", "Hostel City 57", "Znamenskoe on Bogatyrskaya Zastava" and "DOSAAF". The hostels were analyzed according to the following criteria: year of opening, location, the size of room inventory, cost of accommodation, room capacity.

Figure 1 shows growth dynamics of the hostels number in Oryol in accordance with the year of online-entry on booking.com.

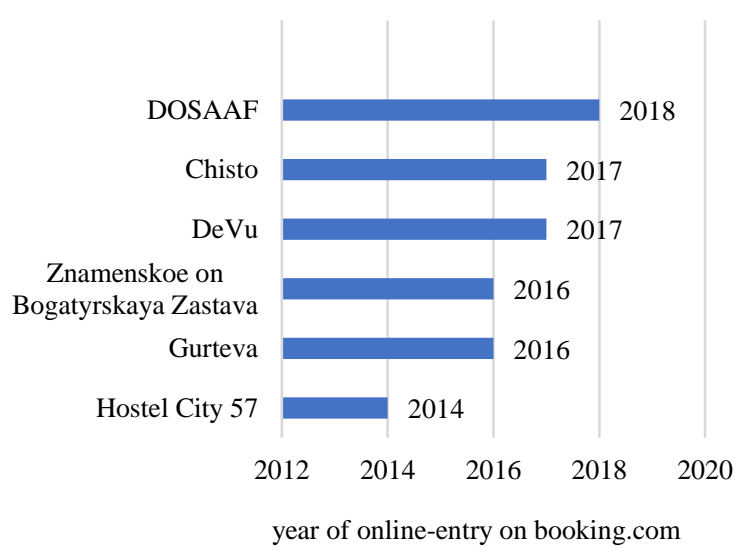

Figure 1 Growth dynamics of the hostels number in Oryol
"Hostel City 57" was one of the first hostels signed up on booking.com - 2014, i.e. today it is "the oldest" hostel in Oryol. In 2015 there were no changes in the hostel services market. In 2016 there was a positive trend in the development of hostels: two more hostels were opened: "Gurteva" and "Znamenskoe on Bogatyrskaya Zastava". This trend is confirmed by the opening of three more hostels over the past 3 years: "DeVu" and "Chisto" (2017), and "DOSAAF" (2018).

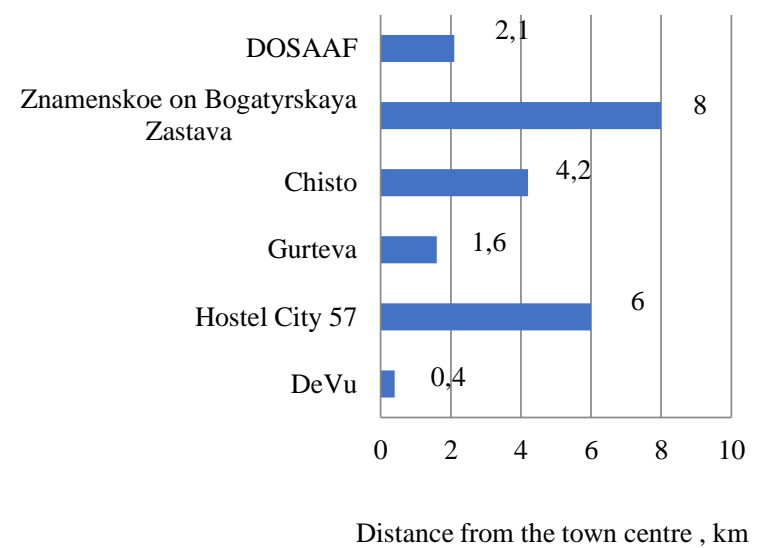

Figure 2 Distribution of hostels by distance from the town center

Analysis of the location (figure 2) enables to determine that hostels are preferably located either in the town center ("DeVu", "Gurteva"), or at the entrance to the town ("Chisto", "DOSAAF"). Their location is related to the concept of offering low-cost accommodation for tourists in the town center, where you can quickly get to the main 


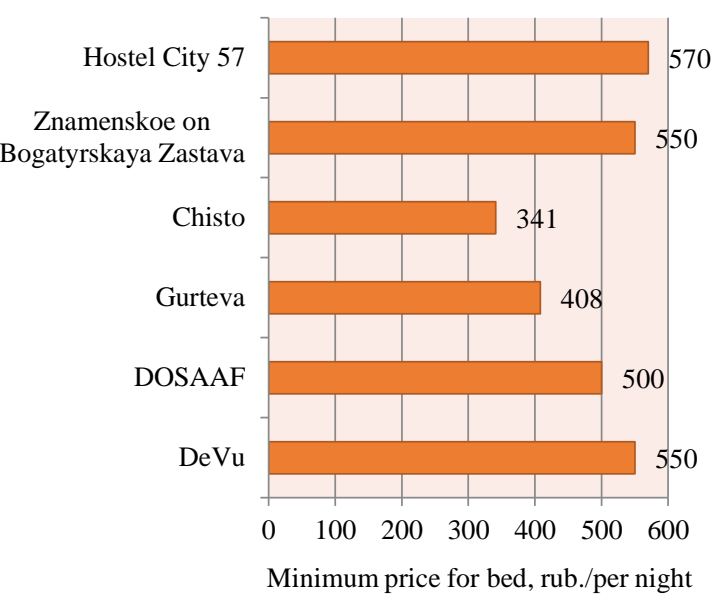

sights. "Hostel City 57" and "Znamenskoe on Bogatyrskaya Zastava" are located remote from the center. Thus, $67 \%$ of the facilities examined are located in the town centre and the surrounding area that suggests a trend towards centralization.

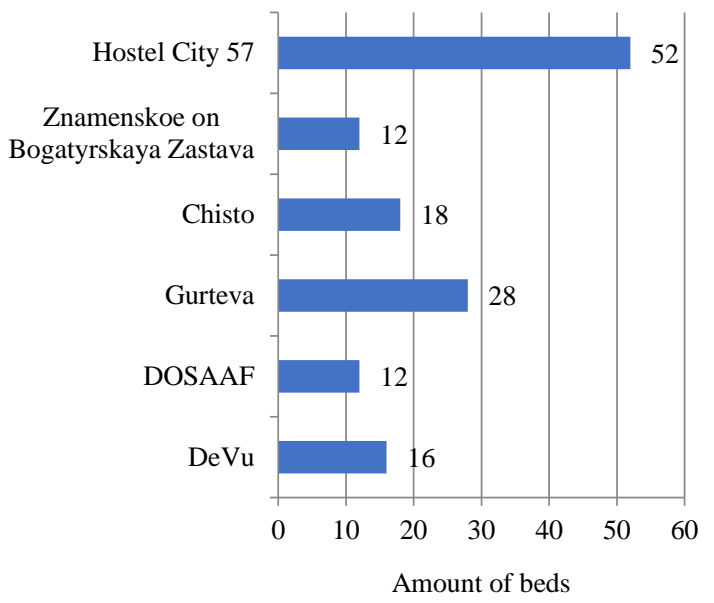

Figure 3 Analysis of hostel capacity by the number of beds

Analysis of the hostels capacity shows that the largest hostels according to the number of beds are "Hostel City 57 " and "Gurteva", their room inventory is 52 and 28 beds, respectively. "Chisto"and "DeVu" are in the second place, with 18 and 16 beds, respectively. The average capacity of other hostels is 12 beds (figure 3 ).

Based on the classification of hostels by the number of living guests given in GOST R 56184-2014 "General requirements for hostels", it is concluded that the most common type of hostels in the Oryol region is mini hostels, which make up $66 \%$ of the facilities examined. "Gurteva" is related to small hostels, and the category of large hostels is represented by "Hostel City 57 ".

The predominance of mini-hostels indicates the problem of the lack of constant high demand for this type of service. Opening of large-capacity hostels in the region is considered to be a risk, since there is possibility that the declared room inventory is not cost-effective, so at the initial stage of development, entrepreneurs in the region try to open hostels with a small room inventory.

The cost of accommodation in the hostel depends on the number of beds in the room - the more the guests, the lower the price. To get statistical information on the price policy of hostels, all the facilities examined were divided into assessment groups at the minimum price of accommodation per guest nights:

- up to 450 rubles - "low price hostels";

- from 450 to 600 rubles- "average price hostels";

- over 600 rubles - "high price hostels".
Figure 4 Analysis of hostels at the minimum price per bed

According to the data presented in figure 4, the highest price per bed in "Hostel City 57" (570 rubles), the cheapest beds are offered by the hostels "Chisto" (341 rubles) and "Gurteva" (408 rubles). The price offers of the remaining $50 \%$ of hostels are approximately in the same price range from 500 to 550 rubles. In all hostels, the cost of a bed includes taxes and fees for accommodation. Analysis of the price policy of regional hostels enables to conclude that it is aimed at attracting bare-bones tourists.

Room capacity of the hostels examined varies from 2 to 10 12 beds. Data on offers for the types of rooms in Oryol hostels are shown in figure 5 .

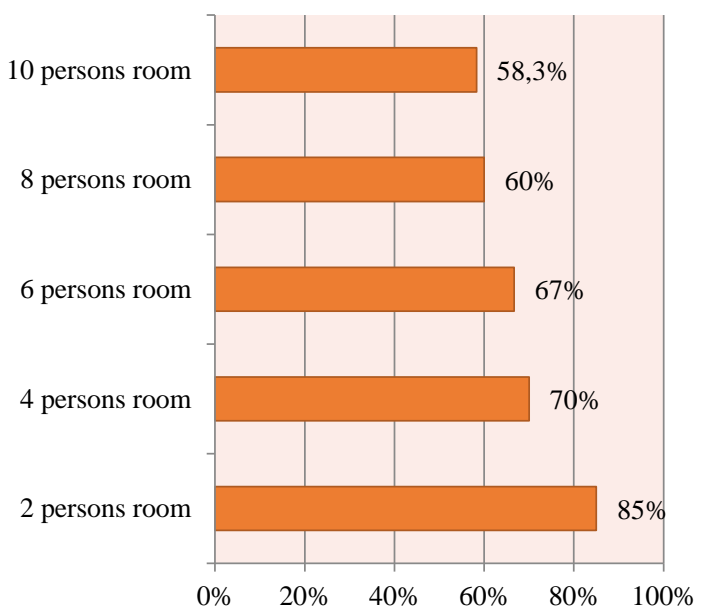

Figure 5 Demand for rooms depending on the number of guests living

Statistics show that small rooms are in much higher demand $(85 \%)$, followed by four-bed $(70 \%)$ and six-bed dormitory $(67 \%)$. The offer more than 10 persons per room is less popular with hostel guests. Having analyzed the results according this criterion, we can conclude that the demand for double rooms with private bathroom has increased and the demand for 10 -and 14 - person rooms has decreased [12]. 
[4] Busch-Geertsema V., Sahlin I. The role of hostels and temporary accommodation // European Journal of Homelessness. 2007. Vol.1. P.67-93.

[5] Otto S., Orford J. Not Quite Like Home - Small Hostels for Alcoholics and Others. New York: John Wiley and Sons, 1978.

[6] Frith T., Hing N. Backpacker hostels and their guests: attitudes and behaviors relating to sustainable tourism // Tourism Management. 1999. Vol. 20. P.251254.

[7] O’Regan M. Backpacker hostels: place and performance / Beyond Backpacker Tourism: Mobilities and Experiences. Ed. by K.Hannan, A.Diekmann. Bristol: Channel View Publications, 2010. P.85-101.

[8] De Oliveira Santos G.E. Worldwide hedonic prices of subjective characteristics of hostels // Tourism Management. 2016. Vol. 52. P.451-454.

[9] Brochardo A., Rita P. Exploring heterogeneity among backpackers in hostels // Current Issues in Tourism. 2018. Vol.21. Issue 13. P.1502-1520.

[10] Quinby D. Beyond the backpacker: how hostels are remaking the low-cost accommodation marketplace / Phocuswright. June 2016. [E-resource]. URL: www.phocuswright.com/Travel-Research/ResearchUpdates/2016/Beyond-the-Backpacker-How-HostelsAre-Remaking-the-Low-Cost-AccommodationMarketplace (access date: 02.03.2020).

[11] Batsyna Ya. V., Belousova N. A., Polenova T. V. Problems and prospects of Russian hostels in the context of global trends / / Annals of the Altai Academy of Economics and Law. - 2019. - № 10-2. - P. 24-30; URL: https://www.vaael.ru/ru/article/view?id=760 (access date: 06.03.2020).

[12] Glebova N.V. Formation of the regional hostel market as a factor of tourism development. Integration of tourism into the economic system of the region: prospects and barriers / / Proceedings of the I International scientific and practical conference 25-26 April, 2019. - Oryol. - P. 469-475
[3] O’Hanlon S. Full board and lodging: hostels for migrant workers in early postwar Melbourne // History Australia. 2005. Vol.2. P.88.1-88.15. 